\title{
Characterization of clinical isolates previously identified as Oerskovia turbata: proposal of Cellulosimicrobium funkei sp. nov. and emended description of the genus Cellulosimicrobium
}

\author{
June M. Brown, Arnold G. Steigerwalt, Roger E. Morey, \\ Maryam I. Daneshvar, Leslie-Joy Romero and Michael M. McNeil†
}

Correspondence

June M. Brown

jmb6@cdc.gov

\begin{abstract}
Meningitis and Special Pathogens Branch; Division of Bacterial and Mycotic Diseases, National Center for Infectious Diseases, Centers for Disease Control and Prevention, Atlanta, GA 30333, USA
\end{abstract}

The genus Cellulosimicrobium was first proposed by Schumann et al. (2001). At present, the genus comprises one species, Cellulosimicrobium cellulans (Schumann et al., 2001). Cellulosimicrobium variable, proposed by Bakalidou et al. (2002), has been re-evaluated, transferred from the genus and reclassified as Isoptericola variabilis (Stackebrandt et al., 2004).

In this paper, we describe the morphological, physiological and biochemical characteristics, antimicrobial susceptibility, whole-cell composition, cellular fatty acid and menaquinone content, 16S rRNA gene sequences and DNA-DNA hybridization of 13 clinical isolates (ten of which were epidemiologically related). A comparison was made with the type strains of Cellulosimicrobium cellulans, Cellulomonas fimi, Cellulomonas hominis, Sanguibacter suarezii and Oerskovia turbata. On the basis of the results of this

tPresent address: Epidemiology and Surveillance Division, National Immunization Program, Centers for Disease Control and Prevention, Atlanta, GA 30333, USA.

The GenBank/EMBL/DDBJ accession numbers for the 16S rRNA gene sequences of Cellulosimicrobium funkei strains W6122 ${ }^{\top}$, W6123, W2796 and W4083 are AY501364 and AY523787-AY523789, respectively. polyphasic study, the clinical isolates represent a novel taxon within the genus Cellulosimicrobium.

Strain W6122 $2^{\mathrm{T}}$ was isolated from the blood of an endocarditis patient and identified in 1975 as O. turbata (Reller et al., 1975; Sottnek et al., 1977). Recently, the clonality of $\mathrm{W} 6122^{\mathrm{T}}$ and three additional blood isolates (strains W2622, W2728 and W2729) from the same patient, as well as six homograft valve isolates (strains W2732, W2734, W2736, W2739, W6120 and W6121), was confirmed (McNeil et al., 2004). In addition, McNeil et al. (2004) found that strain W6122 $2^{\mathrm{T}}$ was more closely related to Cellulosimicrobium cellulans (99.8\% 16S rRNA gene sequence similarity) than to the type strain of O. turbata $(95 \cdot 3 \%)$. Strain W4083, isolated from a patient with acute myelogenous leukaemia with a catheter-related bacteraemia, was also described as O. turbata (LeProwse et al., 1989; McNeil et al., 2004). The two remaining strains, W2796 and W6123, were formerly identified as O. turbata, based primarily on phenotypic characteristics (Sottnek et al., 1977; McNeil et al., 2004). No clinical histories were available for either of these strains, except that strain W2796 was isolated from lung and strain W6123 was isolated from an unknown human source.

All isolates were inoculated onto heart infusion agar with $5 \%$ rabbit blood (BBL Microbiology Systems) and incubated 
at 25 and $35^{\circ} \mathrm{C}$ for 2 days for morphological studies. Gram stain was used to study microscopic morphology. The isolates were examined for the presence of aerial and substrate hyphae at low power $(\times 10$ magnification $)$ under a stereomicroscope. Phenotypic characterization was performed using previously described methods (McNeil et al., 2004) and results are given in the species description. Antimicrobial susceptibilities were determined by a previously described broth microdilution method with cation-supplemented Mueller-Hinton broth (NCCLS, 1997). The antimicrobial agents tested were amikacin, amoxycillin-clavulanic acid, ampicillin, ceftriaxone, ciprofloxacin, clarithromycin, imipenem, minocycline, trimethoprim-sulfamethoxazole and vancomycin. Plates were incubated at 25 or $35^{\circ} \mathrm{C}$ for $48 \mathrm{~h}$. Since the methods of testing and the break-points for resistance for the genus have not been standardized or approved by the NCCLS, the break-points used for resistance were those of NCCLS for organisms that grow aerobically (NCCLS, 1997). The break-point for resistance for clarithromycin was taken from the recently NCCLS-approved standard for the susceptibility testing of mycobacteria, nocardiae and other aerobic actinomycetes (NCCLS, 2003).

The genomic DNAs of the isolates were purified from lysed protoplasts as described previously (Lasker et al., 1992). DNA labelling and DNA-DNA relatedness experiments were performed with strain $\mathrm{W} 6122^{\mathrm{T}}$ and strains W2796, W4083 and W6123 and the type strains of Cellulosimicrobium cellulans and $O$. turbata using the hydroxyapatite method described by Brenner et al. (1982). Strain $\mathrm{W} 6122^{\mathrm{T}}$ was related to strains W2796 (76\%), W4083 (78\%) and W6123 $(79 \%)$, with a divergence $\left(\Delta T_{\mathrm{m}}\right)$ of $1 \cdot 5,2 \cdot 0$ and $1.5 \%$, respectively, but showed low DNA-DNA relatedness to Cellulosimicrobium cellulans ATCC $12830^{\mathrm{T}}(47 \%)$ and $O$. turbata ATCC $25835^{\mathrm{T}}(3 \cdot 0 \%)$.

The DNA G + C content was determined spectrophotometrically by thermal denaturation as described previously (Mandel et al., 1970). The DNA G +C content of strain $\mathrm{W} 6122^{\mathrm{T}}$ was $74.5 \mathrm{~mol} \%$. This value was consistent with the DNA G +C content of $74 \mathrm{~mol} \%$ observed for the genus Cellulosimicrobium (Schumann et al., 2001).
The 16S rRNA genes of strains W6122 ${ }^{\mathrm{T}}$, W2796, W4083, W6123 and Cellulosimicrobium cellulans ATCC $12830^{\mathrm{T}}$ were analysed as described by McNeil et al. (2004). A continuous stretch of $1444 \mathrm{nt}$ of the 16S rRNA gene sequence was determined and used for comparative phylogenetic analysis. Related sequences were identified in a BLAST search against the GenBank database. Sequences were aligned and a distance matrix was created with CLUSTAL W. A phylogenetic tree was constructed in TREECON with the neighbour-joining method (Fig. 1) and bootstrapped with 1000 replications (McNeil et al., 2004). The 16S rRNA gene sequence similarity values between strains W6122 ${ }^{\mathrm{T}}$, W2796, W4083 and W6123 ranged from $99 \cdot 8$ to $100 \%$. The sequence similarity values between these strains and Cellulosimicrobium cellulans ATCC $12830^{\mathrm{T}}$ ranged from $99 \cdot 5$ to $99 \cdot 8 \%$.

Results of the chemotaxonomic analyses are given in the species description. The following analytical procedures were performed: diaminopimelic acid and monosaccharide whole-cell analysis (Berd, 1973), cellular fatty acid analysis (Weyant et al., 1996) and quinone analysis (Moss \& Guerrant, 1983). Whole-cell analyses of the organisms indicated that they contained neither the meso- nor the L-isomer of diaminopimelic acid. Galactose was the only characteristic whole cell-wall sugar found. The presence of only galactose is not consistent with the cell-wall sugars identified from Cellulosimicrobium cellulans; thus, this characteristic may be useful for species differentiation (Stackebrandt et al., 2004).

The strains share a similar respiratory quinone profile that is characterized by large amounts of menaquinone-9 [MK$\left.9\left(\mathrm{H}_{4}\right)\right]$. Predominant fatty acids are 12-methyltetradecanoic acid (ai- $\left.\mathrm{C}_{15: 0}\right)$, 14-methylpentadecanoic acid (i- $\mathrm{C}_{16: 0}$ ), hexadecanoic acid $\left(\mathrm{C}_{16: 0}\right)$ and 13-methyltetradecanoic acid $\left(\mathrm{i}-\mathrm{C}_{15: 0}\right)$. The fatty acid profile of strain $\mathrm{W} 6122^{\mathrm{T}}$ was similar to that of Cellulosimicrobium cellulans ATCC $12830^{\mathrm{T}}$.

In contrast to the chemotaxonomic similarities between strains $\mathrm{W} 6122^{\mathrm{T}}$ and Cellulosimicrobium cellulans, the only other species of the genus Cellulosimicrobium, clear differences were seen in the results of phenotypic tests (Table 1).

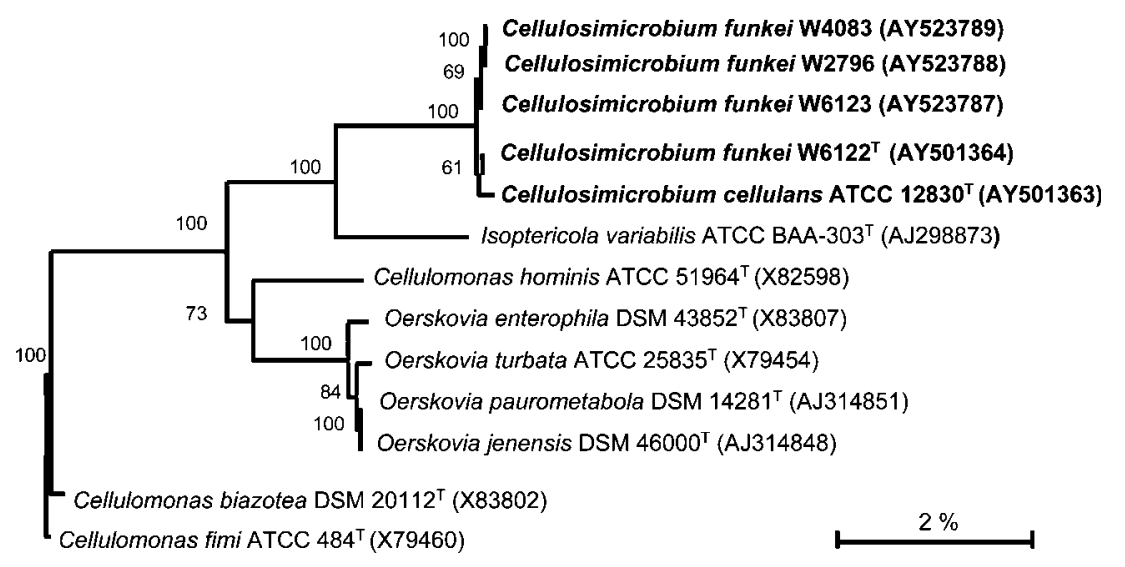

Fig. 1. Neighbour-joining phylogenetic tree based on 16S rRNA gene sequences showing the position of Cellulosimicrobium funkei sp. nov. strains W4083, W2796, W6123 and $\mathrm{W} 6122^{\top}$ and Cellulosimicrobium cellulans ATCC $12830^{\top}$. The tree was rooted by using Cellulomonas fimi as the outgroup. Bar, $2 \%$ difference in nucleotide sequence. 
Table 1. Phenotypic characteristics that differentiate strains $W 6122^{\top}, W 2796, W 4083$ and $W 6123$ from related species and genera

Reference strains: 1, Cellulosimicrobium cellulans ATCC $12830^{\mathrm{T}} ; 2$, Cellulomonas hominis ATCC $51964^{\mathrm{T}}$; 3, Cellulomonas fimi ATCC $484^{\mathrm{T}}$; 4, Sanguibacter suarezii ATCC $51766^{\mathrm{T}}$; 5, Oerskovia turbata ATCC $25835^{\mathrm{T}}$. All strains were positive for acid production from fructose, D-galactose, D-glucose, lactose, maltose, salicin, sucrose, D-trehalose and D-xylose. All strains were negative for acid production from adonitol, dulcitol, i-erythritol, myo-inositol and D-mannitol. All strains were negative for the hydrolysis of tyrosine. All strains grew at $25^{\circ} \mathrm{C}$, but not at $45^{\circ} \mathrm{C}$. All strains were susceptible to amoxycillin-clavulanic acid, ampicillin, ceftriaxone, clarithromycin, minocycline and vancomycin. All strains have a convex and entire-edged macroscopic morphology. In addition, Sanguibacter suarezii ATCC $51766^{\mathrm{T}}$ has been described as having a 'fried egg' morphology. Data for the type strains of related species and genera were derived from the CDC's Meningitis and Special Pathogens Branch database. For antibiotic resistance, the minimum inhibitory concentration (MIC) resistance break-points used are those of the NCCLS $(1997,2003)$. +, Positive; -, negative; (+), weakly positive; HIA, heart infusion agar.

\begin{tabular}{|c|c|c|c|c|c|c|c|c|c|}
\hline Characteristic & \multicolumn{4}{|c|}{ Cellulosimicrobium funkei sp. nov. } & 1 & 2 & 3 & 4 & 5 \\
\hline L-Arabinose & + & + & - & + & + & + & + & + & + \\
\hline Cellobiose & + & + & + & + & $(+)$ & + & + & + & + \\
\hline Glycerol & + & + & - & + & $-1+^{*}$ & + & - & - & + \\
\hline Melezitose & - & - & - & - & - & - & + & - & - \\
\hline Melibiose & - & + & - & - & + & - & + & + & - \\
\hline Raffinose & - & - & - & - & $(+)$ & - & + & + & - \\
\hline L-Rhamnose & - & - & - & - & - & + & + & + & - \\
\hline D-Sorbitol & - & - & - & - & - & - & - & + & - \\
\hline \multicolumn{10}{|l|}{ Hydrolysis of: } \\
\hline Adenine & + & + & + & + & + & - & - & - & - \\
\hline Casein & + & + & + & + & + & - & - & - & - \\
\hline Hypoxanthine & + & + & + & + & + & - & - & - & - \\
\hline Xanthine & + & + & + & + & + & - & - & - & - \\
\hline Substrate hyphae & + & + & + & + & + & - & - & - & + \\
\hline Motility & $+\dagger$ & + & + & + & - & + & + & + & + \\
\hline $\begin{array}{l}\text { Urease production (Christensen urea } \\
\text { agar slant) }\end{array}$ & + & + & $(+)$ & $(+)$ & + & $+1-\ddagger$ & - & - & - \\
\hline Nitrate reduction & - & + & + & + & + & + & + & + & + \\
\hline Gelatin liquefaction (14 days) & + & + & + & + & + & $-1+\ddagger$ & - & - & + \\
\hline \multicolumn{10}{|l|}{ Resistance to: } \\
\hline
\end{tabular}

${ }^{\star}$ Schumann et al. (2001) described acid production from glycerol.

$\dagger$ One to five polar or/or lateral flagella were seen on all motile isolates (Sottnek et al., 1977).

$\ddagger$ Funke et al. (1995) described Cellulomonas hominis as urease-negative using Christensen broth and gelatin-positive using the film strip method.

Strains W6122 ${ }^{\mathrm{T}}$, W2796, W4083 and W6123 lacked the ability to produce acid from inulin and raffinose and were motile, whereas Cellulosimicrobium cellulans ATCC $12830^{\mathrm{T}}$ produced acid from inulin and raffinose and was nonmotile. Table 1 lists additional phenotypic properties that distinguish strains W6122 ${ }^{\mathrm{T}}$, W2796, W4083 and W6123 and Cellulosimicrobium cellulans ATCC $12830^{\mathrm{T}}$ from related species and genera. The high levels of DNA-DNA relatedness demonstrate that these isolates represent the same species and the low levels of sequence similarity to other genera support the distinctness of these isolates (Fig. 1).

Microscopic morphological studies showed that all isolates studied were Gram-positive, pleomorphic bacilli, lacking 
spores and capsules. Under low-power stereomicroscopic examination, the isolates showed pale-yellow to yellow, small diameter (approx. $1 \mathrm{~mm}$ ) colonies after incubation on heart infusion agar with $5 \%(\mathrm{v} / \mathrm{v})$ rabbit blood for 2 days at $35^{\circ} \mathrm{C}$. Substrate hyphae were seen. All colonies were smooth, convex and entire-edged. All isolates studied were motile, with lateral or polar flagella or both (Sottnek et al., 1977).

\section{Emended description of Cellulosimicrobium Schumann et al. 2001}

Cellulosimicrobium (Cell.u.lo.si.mi.cro'bi.um. N.L. n. cellulosa cellulose; Gr. adj. mikros small; Gr. masc. n. bios life; N.L. neut. n. Cellulosimicrobium cellulose microbe).

The Neo Latin noun Cellulosimicrobium is in the neuter gender and not in the feminine gender as cited by Schumann et al., 2001 [all Latin names which end in -um (nominative singular) are assigned neuter gender].

The description is as given by Schumann et al., 2001, with the following modifications. Whole-cell sugars are galactose, rhamnose, glucose, fucose and mannose or galactose and ribose. Motile or non-motile. Nitrate reduction is positive or negative.

\section{Description of Cellulosimicrobium funkei sp. nov.}

Cellulosimicrobium funkei (fun'ke.i. N.L. gen. masc. n. funkei of Funke, to honour the contributions of Guido Funke, a distinguished microbiologist, who recognized the heterogeneity within the yellow-pigmented coryneform bacteria).

Cells are short $(1 \mu \mathrm{m})$, thin, Gram-positive and nonsporulating rods. Motile by polar and/or lateral flagella (Sottnek et al., 1977). Growth occurs at 35 and $45^{\circ} \mathrm{C}$, but not at $25^{\circ} \mathrm{C}$. Pale-yellow pigment. Substrate hyphae are present. Catalase-positive. Aesculin, adenine, casein, gelatin, hypoxanthine, urea and xanthine are decomposed. Nitrate is not reduced to nitrite (Sottnek et al., 1977). Acid is produced from L-arabinose, cellobiose, fructose, D-galactose, Dglucose, glycerol, lactose, maltose, mannose, salicin, sucrose, D-trehalose and D-xylose. No acid production from adonitol, dulcitol, i-erythritol, myo-inositol, inulin, D-mannitol, melezitose, melibiose, raffinose, L-rhamnose or D-sorbitol. DNA G + C content is $74.5 \mathrm{~mol} \%$. The characteristic wholecell sugar is galactose.

The type strain, $\mathrm{W}^{2} 122^{\mathrm{T}} \quad\left(=\mathrm{ATCC}\right.$ BAA $-886^{\mathrm{T}}=\mathrm{DSM}$ $16025^{\mathrm{T}}=$ CCUG $50705^{\mathrm{T}}$ ), was isolated from human blood.

\section{References}

Bakalidou, A., Kämpfer, P., Berchtold, M., Kuhnigk, T., Wenzel, M. \& König, H. (2002). Cellulosimicrobium variable sp. nov., a cellulolytic bacterium from the hindgut of the termite Mastotermes darwiniensis. Int J Syst Evol Microbiol 52, 1185-1192.

Berd, D. (1973). Laboratory identification of clinically important aerobic actinomycetes. Appl Microbiol 25, 665-681.

Brenner, D. J., McWhorter, A. C., Knutson, J. K. \& Steigerwalt, A. G. (1982). Escherichia vulneris: a new species of Enterobacteriaceae associated with human wounds. J Clin Microbiol 15, 1133-1140.

Funke, G., Ramos, C. P. \& Collins, M. D. (1995). Identification of some clinical strains of CDC coryneform group A-3 and A-4 bacteria as Cellulomonas species and proposal of Cellulomonas hominis sp. nov. for some group A-3 strains. J Clin Microbiol 33, 2091-2097.

Groth, I., Schumann, P., Rainey, F. A., Martin, K., Schuetze, B. \& Augsten, K. (1997). Bogoriella caseilytica gen. nov., sp. nov., a new alkaliphilic actinomycete from a soda lake in Africa. Int $J$ Syst Bacteriol 47, 788-794.

Lasker, B. A., Brown, J. M. \& McNeil, M. M. (1992). Identification and epidemiological typing of clinical and environmental isolates of the genus Rhodococcus with use of a digoxigenin-labeled rDNA gene probe. Clin Infect Dis 15, 223-233.

LeProwse, C. R., McNeil, M. M. \& McCarty, J. M. (1989). Catheterrelated bacteremia caused by Oerskovia turbata. J Clin Microbiol 27, 571-572.

Mandel, M., Igambi, L., Bergendahl, J., Dodson, M. L., Jr \& Scheltgen, E. (1970). Correlation of melting temperature and cesium chloride buoyant density of bacterial deoxyribonucleic acid. J Bacteriol 101, 333-338.

McNeil, M. M., Brown, J. M., Carvalho, M. E., Hollis, D. G., Morey, R. E. \& Reller, L. B. (2004). Molecular epidemiologic evaluation of endocarditis due to Oerskovia turbata and CDC Group A-3 associated with contaminated homograft valves. J Clin Microbiol 42, 2495-2500.

Moss, C. W. \& Guerrant, G. O. (1983). Separation of bacterial ubiquinones by reverse-phase high-pressure liquid chromatography. J Clin Microbiol 18, 15-17.

NCCL (1997). Methods for dilution antimicrobial susceptibility tests for bacteria that grow aerobically. Approved standard M7-A6. Wayne, PA: National Committee for Clinical Laboratory Standards.

NCCL (2003). Susceptibility testing of mycobacteria, nocardiae, and other aerobic actinomycetes. Approved standard, NCCLS document M24-A. Wayne, PA: National Committee for Clinical Laboratory Standards.

Reller, L. B., Maddoux, G. L., Eckman, M. R. \& Pappas, G. (1975). Bacterial endocarditis caused by Oerskovia turbata. Ann Intern Med 83, 664-666.

Schumann, P., Weiss, N. \& Stackebrandt, E. (2001). Reclassification of Cellulomonas cellulans (Stackebrandt and Keddie 1986) as Cellulosimicrobium cellulans gen. nov., comb. nov. Int J Syst Evol Microbiol 51, 1007-1010.

Sottnek, F. O., Brown, J. M., Weaver, R. E. \& Carroll, G. F. (1977). Recognition of Oerskovia species in the clinical laboratory: characterization of 35 isolates. Int J Syst Bacteriol 27, 263-270.

Stackebrandt, E., Schumann, P. \& Cui, X.-L. (2004). Reclassification of Cellulosimicrobium variable Bakalidou et al. 2002 as Isoptericola variabilis gen. nov., comb. nov. Int J Syst Evol Microbiol 54, 685-688.

Weyant, R. S., Moss, C. W., Weaver, R. E., Hollis, D. G., Jordan, J. J., Cook, E. C. \& Daneshvar, M. I. (1996). Identification of Unusual Pathogenic Gram-negative Aerobic and Facultatively Anaerobic Bacteria, 2nd edn. Baltimore: Williams \& Wilkins. 